Saudi Journal of Humanities and Social Sciences

Abbreviated Key Title: Saudi J Humanities Soc Sci

ISSN 2415-6256 (Print) | ISSN 2415-6248 (Online)

Scholars Middle East Publishers, Dubai, United Arab Emirate

Journal homepage: https://saudijournals.com/sjhss

Original Research Article

\title{
Teachers' 21st-Century Skills: How do Saudi EFL Students Evaluate their Use?
}

\author{
Hayat Rasheed H. Alamri* \\ Curricula \& Teaching Methods Department College of Education Taibah University - KSA
}

DOI: $10.36348 /$ sjhss.2020.v05i02.003

| Received: 10.02.2020 | Accepted: 19.02.2020 | Published: 27.02.2020

*Corresponding author: Hayat Rasheed Hamzah Alamri

\section{Abstract}

This descriptive research method design explored how Saudi EFL female students value their teachers' use of 21st Century Skills and how these skills improve their language skills. Two closed-item questionnaires were designed for two data collection phases and distributed to EFL female students in the Preparatory Year Programme (PYP) at Taibah University, Saudi Arabia: 548 students in phase one and 226 in phase two. The results revealed that the participants valued their teachers' 21st Century skills very positively, ranking all items in the questionnaire "excellent". Moreover, the results indicated that "life and career" skill set and its sub-dimension "social and cross-cultural skills" obtained the highest mean scores. The results emphasized the improvement of students' language skills, particularly vocabulary and speaking skills, that contributed was to EFL teachers' implementation of 21 st Century skills.

Keywords: 21st Century skills; EFL Saudi students; Preparatory Year Programme (PYP); language skills and aspects.

Copyright @ 2020: This is an open-access article distributed under the terms of the Creative Commons Attribution license which permits unrestricted use, distribution, and reproduction in any medium for non-commercial use (NonCommercial, or CC-BY-NC) provided the original author and source are credited.

\section{INTRODUCTION}

Global changes in social and economic systems along with competitive local and international market demands have resulted in immense growth and widespread in knowledge and information communication technologies (ICTs) [1, 2]. Education is now, more than ever, seen as the key to social and economic progress. In other words, one of the key elements of successful change is a 21st Century education that is less focus on knowledge and more emphasis on improving the quality of teaching-learning processes [3].

Furthermore, social and economic factors increase students' challenge to acquire needed skills and knowledge to be competent in the 21st Century [4]. Thus, education philosophy is placing much more emphasis than ever before on gaining the necessary $21 \mathrm{st}$ Century skills to meet the demands of society [5]. As stated by [6] "the skills of the 21 st-century include neither skill nor knowledge alone. 21st-century skills include understanding and performance. In other words, it is a blend of knowledge and skill (p. 252)." Hence, to cope with the demands of the 21 st Century, learners need to have more than basic skills. Individuals need to build up higher level skills in order to acquire knowledge, analyse information, comprehend new ideas, solve problems, make decisions and, in time, convert knowledge and information into competitive products [7-10].

In line with the philosophy that "every learner is different; therefore, one-size-fits-all models suit no one" [11], today's students need to be exposed to a variety of activities, appropriate technology tools, innovative teaching methods, such as project-based learning, inquiry-based learning, problem-solving situations, and collaborative learning environments. [12] Added that a specific focus on 21st Century skills, such as creativity, critical thinking, communication and collaboration, known as the $4 \mathrm{Cs}$, can help provide students with the qualities they will need for future success. As Well, the Organization for Economic Cooperation and Development (OECD) believes that students who are best prepared for the 21 st Century can have a positive influence on their environments, understand others' actions and feelings, and pay much attention to their learning [13]. Therefore, as Saavedra and Opfer [4] state, educators must broaden their perspectives to include $21 \mathrm{st}$ Century skills in the curriculum and co-curricular activities.

A number of researchers have highlighted the importance of 21st Century skills. Sahin [10], states that learners have to learn 21 st Century learning skills to 
solve the new problems of the new world. Pheeraphan [14] investigated the beneficial effect of integrating $21 \mathrm{st}$ Century skills, specifically, information and communication technology (ICT), in the classroom. The results showed that the integration of ICT could significantly enhance 21 st Century learning skills. A Finnish study conducted by Ahonen and Kinnunen [15] with 718 students rated social and collaboration skills as the most essential 21st Century skills to have, while Ongardwanich, Kanjanawasee, and Tuipae [16] identified life and career skills with their subsumed skills to be the most relevant 21 st Century skills.

Moreover, some literature has focused on the importance of teachers having 21st Century Skills and the role these play in preparing students for the demands of 21 st Century life. For example, a report issued by OECD, entitled "Teachers Matter", based on a wide range of studies, revealed that teachers' skills, competencies, and qualities crucially affected students' learning [13]. As well, Jan [17] concluded that good teaching is increasingly cited as a major determinant of learning productivity and quality of education. Therefore, teachers in the 21 st Century should possess knowledge, skills, and competencies necessary for their careers and society. Saavedra and Opfer [1] argued that teachers need to have 21 st Century skills themselves to be able to teach such skills, manage effective teaching and learning practices, and help students use the knowledge they gain in their daily lives.

As indicated by Kobalia and Garakanidze [18], a teacher should not only be a provider of knowledge, but should also have a positive attitude towards innovations and should be willing to undertake self-development and use student-centered teaching approaches. Kostanjevec, Kozina, and Erjavšek [19] recommend that teachers with outdated skills should be provided with additional professional development. Prasertcharoensuk et al. [9] add that frequent professional development improves teachers' $21 \mathrm{st}$ Century skills as well as enhances students' life skills. Orr et al. [3] indicate that professional development allows 21st Century teachers to revise their educational resources, provide a better fitting educational environment and leads to higher levels of collaboration and interaction between teachers.

Several studies have documented teachers' 21 st Century skills' significant effect on teaching and learning processes. For instance, Kan and Murat [8] examined the perceptions of prospective Turkish science teachers towards 21 st Century skills. The results revealed that teachers value learning and innovation skills, life and career skills, and information, media and technology skills, all of which are essential 21st Century skill sets. Oudeweetering and Voogt [20] analysed the responses of 2,804 teachers and found that classroom activities helped foster some 21st Century skills such as digital literacy, critical thinking, communication, innovative thinking, self-regulated learning, and collaborative learning. Hence, the teachers involved in this study strongly believed in the importance of integrating 21st Century skills in the curriculum. The findings of Tican and Deniz's [21] study revealed that pre-service teachers are ready to use certain 21st Century learner skills such as cognitive skills, collaboration and flexibility skills, innovativeness skills, autonomous skills, technopedagogical skills, administrative skills, and generative skills.

To date, there have been few research studies that have focused on the theoretical underpinnings of evaluating teachers' 21 st Century skills from the students' perspective. Thus, there is a need to fill this gap in this research area.

\section{Statement of the problem}

Saudi students in the Preparatory Year Programme (PYP) at Taibah University in Madinah, Saudi Arabia are taught English as a foreign language (EFL) for 16 hours per week under the auspices of the English Language Centre (ELC). The EFL textbook used is $Q$ : Skills for Success $\left(2^{\text {nd }}\right.$ ed) (See https://cutt.us/hbwII). Some of the general key features of the textbook are: (1) a question-centered approach that encourages students to think critically; (2) a video in every unit that brings critical situations for students; (3) iTools Online to increase student engagement; and (4) the e-Book versions with interactive features designed to help learners achieve their language learning goals. For the EFL teacher, iTools Online is considered as an all-in-one classroom utility that allows them to interact willingly and enthusiastically with the page content.

EFL teachers in the PYP at Taibah University concur with Norahmi's [22] statement that teaching the subject matter is not very complicated since this relates to the teacher's educational background. The challenge for the teacher is to design dynamic and innovative learning activities to catch the attention of the students. Teachers should be more broad-minded to facilitate more critical-thinking learning opportunities. The EFL teachers at the PYP are confident that EFL students need to apply their language knowledge in evolving circumstances. They also need a broad range of skills including creativity, innovation, communication, collaboration, critical thinking, problem-solving and ICT literacy.

Hence, the EFL teachers in the PYP teach the textbook Q: Skills for Success using a variety of innovative and interactive language teaching methods. They teach listening, speaking, reading, writing, vocabulary, and grammar through debates, decisionmaking, inquiry-based learning, oral presentations, brainstorming, problem-solving, project-based learning, focus groups, seminars, simulations, story-telling and 
workshops among other activities. Moreover, they use informal activities to enhance peer-interactions and treat the students as agents of their own language learning. As observed by the researcher, the PYP teachers can create dynamic language-learning environments, provide opportunities for deep discussions, integrate high-tech facilities to foster language learning, and use different authentic assessment techniques to measure performance. In other words, they are able to apply $21 \mathrm{st}$ Century skills in their EFL classrooms. Furthermore, the ELC has established a professional learning community (PLC) where EFL teachers meet once a week to share achievements, discuss challenges, solve problems, and obtain recommendations of activities to use with their PYP students.

Although there is a growing body of literature that recognises the importance of EFL teachers' 21st Century skills [23, 22, 24, 25]., there is a considerable gap in research that evaluates such skills from the students' perspective. To partly fill this gap, this study explores how Saudi EFL female students in the PYP evaluate their teachers' use of 21 st Century skills and the improvement of students' language skills based on the implementation of 21 st Century skills in teachinglearning process.

\section{Research questions}

- How do Saudi EFL female students evaluate their teachers' use of 21 st Century skills?

- What are the views of Saudi EFL female students concerning the contribution of teachers' use of 21 st Century skills in their language skills?

\section{Literature review}

This section presents a review of (1) towards a definition of 21st Century skills, (2) 21st Century learning framework, and (3) 21st Century skills in EFL classrooms.

\section{Towards a definition of 21st Century skills}

Although the term "21st Century skills" is widely used in education, it is not always defined consistently, which can lead to divergent interpretations. As well, a number of related terms are widely used to refer to 21 st Century skills - including applied skills [25], soft skills, life skills, socialemotional skills [26], generic skills [15], high level thinking skills $[8,10]$ transferable skills [27], and noncognitive skills [28]. Additionally, specific 21st Century learning skills may be defined and categorised differently according to factors such as type of institution, age, gender, social and economy demands and country strategic plans. Recently, the Glossary of Education Reform [29], defined 21st Century skills as "a broad set of knowledge, skills, work habits, and character traits that are believed-by educators, school reformers, college professors, employers, and othersto be critically important to success in today's world, particularly in collegiate programs and contemporary careers and workplaces."

On the other hand, although 21 st Century skills are classified in different ways, there are a number of overlaps among definitions that typically include the following skills: creativity, critical thinking, problemsolving, collaboration, communication, responsibility, leadership, technology integration, interaction, and flexibility.

\section{1st Century learning framework}

Educational planners, theoreticians, and researchers all over the world have attempted to develop a number of frameworks of necessary skills for 21 st Century students to be successful in both the local and global societies [21].

In pursuit of this aim, OEDC has provided a framework that can guide the Definition and Selection of Competencies (DeSeCo) of the 21st Century [2]. The European Parliament and the Council of the European Union (EPCEU) established a system of reference identifying the basic skills needed for lifelong learning as a key measure in Europe's response to globalization and the transition to knowledge-based economics [38].

In the US, the Partnership for 21st Century Skills (P21), a joint government-corporate organisation, created a 21 st Century learning model that identifies the skills, knowledge and expertise that students need to acquire to succeed in their future careers and life [35].

The Learning Metrics Task Force (LMTF), a joint effort with UNESCO, aims to create a shift in global education [33]. A report presented by Bialik and Fadel [34] for the Center for Curriculum Redesign in Switzerland aims to redesign the curriculum by offering a holistic framework across the four academic dimensions: knowledge, skills, character, and metacognition. In Canada, a document administered by the Ontario Public Service and managed by the Canadian Ministry of Education aims to provide a focus for discussions among ministry and external policymakers and research experts to renew Ontario's vision for education [36].

This study adapts the P21 framework is considered to be a unified, collective vision for learning [37].

For the most part, the P21framework seems to be in line with Saudi Arabia Vision 2030 (SAV2030) that was developed by the Council of Economic and Development Affairs. The vision focuses on three primary themes: a vibrant society, a thriving economy, and an ambitious nation. Moreover, the SAV2030 plan is seen as the first step towards achieving Saudi Arabia's economic goals and changes in Saudi society [32]. 
An adaptation of P21 may assist in achieving one of the main goals of SAV2030 in the educational sector, which is "to provide the education that builds our children's fundamental characters" (p. 29). Moreover, similar to the P21, the SAV2030 seeks to shift to online learning to enable the development of teachers and students which was a cornerstone of the Saudi National Transformation Programme (NTP).

\section{1st Century skills in EFL classrooms}

Handayani [23] stated that school education is no longer about "a traditional classroom where teachers as the only source of knowledge", on contrary, students should be equipped with 21 st Century skills for a successful future. Based on this claim, English language teachers have a vital role to play in their classes as teaching and learning English requires significant effort to be acquired efficiently. Hence, effective EFL teachers should comprehend the theoretical foundations, characteristics, skills, and competencies relating to the 21 st Century and integrate innovative teaching methods and activities such as modelling, coaching, scaffolding, reflection, and exploration and other supportive techniques to match the individual differences among students.

Several studies have documented the significance of 21st Century skills to EFL classrooms. A seminal study in this area was carried out by Thang et al. [24] whose preliminary study reveals that both students and their teachers respond positively to the implementation of Digital Storytelling (DST) to teach English for Academic Purposes (EAP). The review of the preliminary findings focused on the extent to which the innovative teaching method improves the promotion of 21st Century skills including interactive communication skills, interpersonal skills, technology literacy skills, and language skills.

A recent key study by Norahmi [22] aimed to collect respondents' written opinions of the activities implemented by teachers in the teaching-learning process. The results revealed that most students expected the 21st Century teachers to have skills in today's technology and 21st Century student future characteristics.

The findings of the detailed literature review conducted by Ahmadi [30] showed that the use of technology enhances the levels of interaction between EFL teachers and learners, develops thinking skills, facilitates student-centered approach, and promotes learners' autonomy, self-confidence and motivation to learn a foreign language effectively.

A similar study carried out by Howlett and Waemusa [31] examined the extent to which Thai EFL high-school students predicted that smart devices increase learners' knowledge and satisfaction. The results of a questionnaire constructed around $21 \mathrm{st}$
Century learning skills revealed that students agreed and strongly agreed that mobile devices increased their learning and satisfaction. Moreover, they indicated their readiness for autonomous learning using mobile devices in conjunction with their 21 st Century learning skills.

In his more recent study, Bedir [7] investigated the beliefs and perceptions of EFL pre-service teachers on learning and innovation skills of the 21st Century with special emphasis on the 4Cs. The results indicated that EFL pre-service teachers viewed 21st Century learning as the use of technology in the teachinglearning process. They were also only moderately aware of the 4Cs, although they perceived them very positively.

Asri [27] suggested some unique techniques to be used in 21st Century EFL classrooms to enhance critical thinking during language learning. For example, making videos and multimedia "digital creations", formulating an argument based on collected data, and writing different types of texts for various purposes. Other techniques relating to information and ICT literacy are the management of information flow from a wide range of sources and the use of technology for researching, organising, storing and communicating information. In terms of life skills, students may act as part of the local or global community by solving problems affecting the local or the wider community or making decisions at national and international levels.

Moreover, in order to impart 21st Century skills to students, EFL teachers should be able to use them in the teaching-learning process; as stated by Tican and Deniz [21]: "teachers who train learners of the 21 st Century should be able to apply 21 st Century learner skills in their in-class activities" (p.183). Saavedra and Opfer [4] specified nine lessons for the successful teaching of 21 st Century skills, specifically: the curriculum must be relevant to students' real-life; learning should occur through the discipline; lower and higher-order thinking skills should be developed; students should be taught how to learn on their own; the transfer of learning should be encouraged; misunderstandings should be directly addressed; students should be taught how to collaborate with others and exploit technology to support learning; and, students' creativity should be fostered. In other words, Saavedra and Opfer [4] believe that 21st Century teachers should have powerful learning tools to facilitate students' creativity and enable them to maximise the potential of their formal and informal learning experiences in the global society.

\section{RESEARCH METHODOLOGY}

This study utilized the descriptive method of research. Relatively, this method is appropriate to this study since it aims to explore how Saudi EFL female students value their teachers' use of 21 st Century Skills and how these skills improve their language skills. 


\section{RESEARCH INSTRUMENTS}

For the first data collection phase, a questionnaire was designed by the researcher to explore how Saudi EFL female students evaluate teachers' use of 21st Century skills based on the research objectives and the literature review $[15,28,22,25]$. The questionnaire comprised 40 items divided into three main skill sets: (1) learning and innovation skills which comprised three sub-dimensions (13 items); (2) life and career skills which comprised five sub-dimensions (21 items); and (3) information, media and technology skills (IMTS) which comprised three sub-dimensions (6 items). The participants were expected to rank their preferences on a 4-point Likert scale (Excellent=4, Good=3, Fair=2, \& Poor=1).

To ensure its construct and content validity, the questionnaire was sent to two experts in the Curricula and Teaching Methods Department in the College of Education. Changes were made to the questionnaire following their suggestions. The questionnaire was piloted on 8 students and no further modifications were made given that the students confirming the clarity of all items. In addition, Cronbach's alpha was employed to measure the internal consistency of all the items. The results indicated high levels of internal consistency and reliability among the 40 items covering the 21 st Century skills $(\alpha=0.955)$. The Cronbach's alpha results of the three skill sets also indicated high levels of reliability: learning and innovation skills $(\alpha=0.880)$, life and career skills $(\alpha=0.925)$, and (3) IMTS $(\alpha=0.701)$.

For the second data collection phase, the researcher devised a one-question questionnaire to determine the participants' views on the built-up language skills and/or other language aspects based on the EFL teachers' active performance and dynamic use of 21st Century skills in class. The participants were allowed to select one or more options from the following language skills: listening, speaking, reading, writing, grammar, and vocabulary. Both questionnaires were transferred into electronic formats.

\section{Population and sample}

The population of the research consisted of 1922 EFL female students enrolled in the Preparatory Year Programme (PYP) managed by the Deanship for Academic Services at Taibah University, Saudi Arabia in the 2018-2019 academic year. Considering the purposes of this research, the first quantitative data phase was collected from 548 EFL female students (28.51\% of the population). During the second quantitative data phase collection, the researcher explored the views of 226 EFL female students $(41.24 \%)$ out of the 548 students originally sampled concerning the impact of EFL teachers' use of $21 \mathrm{st}$ Century skills on their language skills.

\section{DATA COLLECTION}

For the first data collection phase, the first questionnaire was submitted online to the population of PYP female students at the Madinah branch of Taibah University, Saudi Arabia, on April 28, 2019. The participants were asked to give their email addresses to enable further communication. For the second data collection phase, the link to the one-question questionnaire was sent via email to the participants who had responded to the first questionnaire on May 5, 2019. The respondents were asked to select one or more language skills in which they had noticed a significant improvement due to EFL teachers' use of 21st Century skills in class.

\section{DATA ANALYSIS}

The responses of the questionnaires were analysed using the Statistical Package for the Social Sciences (SPSS) program Version 23. Descriptive statistics (frequencies, percentages, means and standard deviations) were computed to analyse the data.

\section{RESULTS}

Mainly, 548 Saudi EFL female students out of a population of 1922 completed and returned the first questionnaire. The participants ranked the teachers' use of 21 st Century skills very highly in all the statements. Detailed results are presented in Tables 1 to 12 below.

\section{Research Question 1}

Descriptive statistics were computed to answer the first research question: How do Saudi EFL female students evaluate their teachers' use of 21st Century skills?

\section{Skill Set 1: Learning and innovation skills}

This skill set includes (a) creativity and innovation; (b) critical thinking and problem solving; and (c) communication and collaboration (see Tables 1 to 3$)$.

Table-1: Evaluation of EFL teachers' use of 21st Century skills in terms of creativity and innovation

\begin{tabular}{|l|c|c|c|c|c|c|}
\hline \multicolumn{1}{|c|}{ Creativity \& Innovation Skills } & \multicolumn{3}{|c|}{ The Scale } & \multirow{2}{*}{ Mean } & \multirow{2}{*}{ S.D. } \\
\cline { 2 - 6 } & Excellent & Good & Fair & Poor & & \\
\hline 1. Ability to search, discover and innovate. & 356 & 186 & 4 & 2 & 3.64 & 0.52 \\
& $(65.0)$ & $(33.9)$ & $(0.7)$ & $(0.4)$ & & \\
\hline 2. Ability to think creatively and freely while teaching. & 354 & 170 & 22 & 2 & 3.60 & 0.59 \\
& $(64.6)$ & $(31.0)$ & $(4.0)$ & $(0.4)$ & & \\
\hline $\begin{array}{l}\text { 3. Ability to listen to others' opinions considering } \\
\text { different points of view. }\end{array}$ & 394 & $\begin{array}{c}136 \\
(71.9)\end{array}$ & $\begin{array}{c}14 \\
(24.8)\end{array}$ & $\begin{array}{c}(2.6) \\
(0.7)\end{array}$ & 3.68 & 0.56 \\
\hline $\begin{array}{l}\text { 4. Believing in learners' creative abilities to design } \\
\text { meaningful learning projects. }\end{array}$ & 394 & $\begin{array}{c}118 \\
(71.9)\end{array}$ & $\begin{array}{c}28 \\
(21.5)\end{array}$ & $\begin{array}{c}(5.1) \\
(1.5)\end{array}$ & 3.64 & 0.65 \\
\hline
\end{tabular}


Table 1 demonstrates the students' assessment of EFL teachers' use of 21 st Century skills in terms of creativity and innovation. The results reveal that the Saudi EFL female students who participated in the questionnaire ranked their teachers' 21 st Century skills "excellent" from all aspects. The highest value was awarded to Item 3 "ability to listen to others' opinions considering different points of view" $(\mathrm{M}=3.68$; S.D. =
0.56), followed by Items 1 and 4 "ability to search, discover and innovate", "believing in learners' creative abilities to design meaningful learning projects" that resulted in equal mean scores $(\mathrm{M}=3.64 ;$ S.D. $=0.65 \&$ $\mathrm{M}=3.64$; S.D. = 0.52). Finally, Item 2 "ability to think creatively and freely while teaching" obtained a mean score of $\mathrm{M}=3.60 ;$ S.D. $=0.59$.

Table-2: Evaluation of EFL teachers' use of 21st Century skills in terms of critical thinking and problem solving

\begin{tabular}{|c|c|c|c|c|c|c|}
\hline \multirow[t]{2}{*}{ Critical Thinking \& Problem-Solving Skills } & \multicolumn{4}{|c|}{ The Scale } & \multirow[t]{2}{*}{ Mean } & \multirow[t]{2}{*}{ S.D. } \\
\hline & Excellent & Good & Fair & Poor & & \\
\hline $\begin{array}{l}\text { 1. Ability to show deep understanding and critical and } \\
\text { deduction skills. }\end{array}$ & $\begin{array}{c}390 \\
(71.2)\end{array}$ & $\begin{array}{c}144 \\
(26.3)\end{array}$ & $\begin{array}{c}12 \\
(2.2)\end{array}$ & $\begin{array}{c}2 \\
(0.4)\end{array}$ & 3.68 & 0.53 \\
\hline $\begin{array}{l}\text { 2. Ability to practice analytic reasoning and logic to solve } \\
\text { problems and make decisions. }\end{array}$ & $\begin{array}{c}386 \\
(70.4)\end{array}$ & $\begin{array}{c}134 \\
(24.5)\end{array}$ & $\begin{array}{c}24 \\
(4.4)\end{array}$ & $\begin{array}{c}4 \\
(0.7)\end{array}$ & 3.65 & 0.60 \\
\hline $\begin{array}{l}\text { 3. Ability to analyse and interpret information and build } \\
\text { conclusions. }\end{array}$ & $\begin{array}{c}408 \\
(74.5)\end{array}$ & $\begin{array}{c}126 \\
(23.0)\end{array}$ & $\begin{array}{c}12 \\
(2.2)\end{array}$ & $\begin{array}{c}2 \\
(0.4)\end{array}$ & 3.72 & 0.52 \\
\hline $\begin{array}{l}\text { 4. Ability to criticise different types of problems } \\
\text { creatively. }\end{array}$ & $\begin{array}{c}350 \\
(63.9)\end{array}$ & $\begin{array}{c}178 \\
(32.5)\end{array}$ & $\begin{array}{c}16 \\
(2.9)\end{array}$ & $\begin{array}{c}4 \\
(0.7)\end{array}$ & 3.60 & 0.59 \\
\hline $\begin{array}{l}\text { 5. Evoking motivating questions to generate effective } \\
\text { arguments. }\end{array}$ & $\begin{array}{c}396 \\
(72.3)\end{array}$ & $\begin{array}{c}128 \\
(23.4)\end{array}$ & $\begin{array}{c}22 \\
(4.0)\end{array}$ & $\begin{array}{c}2 \\
(0.4)\end{array}$ & 3.68 & 0.57 \\
\hline
\end{tabular}

Similarly, as Table 2 shows, the participants ranked "excellent" the five items relating to the teachers" "ability to analyse and interpret information and build conclusions" that is considered to be the most valued 21 st Century skill in terms of critical thinking and problem-solving $(\mathrm{M}=3.72 ;$ S.D. $=0.52)$. Moreover, they also ranked Items 1 and 5 linked to "ability to show deep understanding and critical and deduction skills" and "evoking motivating questions to generate effective arguments" highly ( each achieving equal mean scores of $\mathrm{M}=3.68$; S.D. $=0.57 \& \mathrm{M}=$ 3.68; S.D. $=0.53)$. Almost $70.4 \%$ ranked positively high teachers' "ability to practice analytic reasoning and logic to solve problems and make decisions" ( $\mathrm{M}=$ 3.65; S.D. $=0.60)$ and $63.9 \%$ ranked their teachers' "ability to criticise different types of problems creatively” highly $(\mathrm{M}=3.60$; S.D. $=0.59)$.

Table-3: Evaluation of EFL teachers' use of 21st Century skills in terms of communication and collaboration

\begin{tabular}{|l|c|c|c|c|c|c|}
\hline \multicolumn{1}{|c|}{ Communication \& Collaboration Skills } & \multicolumn{3}{|c|}{ The Scale } & Mean & S.D. \\
\cline { 2 - 5 } & Excellent & Good & Fair & Poor & & \\
\hline $\begin{array}{l}\text { 1. Incorporating teaching strategies that evoke } \\
\text { interaction and thinking skills. }\end{array}$ & $\begin{array}{c}348 \\
(63.5)\end{array}$ & $\begin{array}{l}172 \\
(31.4)\end{array}$ & $\begin{array}{c}20 \\
(3.6)\end{array}$ & $\begin{array}{c}8 \\
(1.5)\end{array}$ & 3.57 & 0.64 \\
\hline $\begin{array}{l}\text { 2. Communicating effectively with learners both } \\
\text { written and oral in a variety of contexts. }\end{array}$ & 396 & 134 & 12 & 6 & 3.68 & 0.57 \\
\hline $\begin{array}{l}\text { 3. Valuing the contribution of each member in- } \\
\text { group work. }\end{array}$ & $\begin{array}{c}(72.3) \\
(24.5)\end{array}$ & $(2.2)$ & $(1.1)$ & & \\
\hline 4. Stimulating learner' communication with others. & $390.8)$ & $(27.0)$ & $(1.5)$ & $(0.7)$ & 3.68 & 0.54 \\
& $(71.2)$ & $(23.7)$ & $(3.6)$ & $(1.5)$ & 3.65 & 0.62 \\
\hline
\end{tabular}

Based on the above results, a significant number of participants $(72.3 \%)$ rated highly how their teachers "communicate effectively" and more than two-thirds $(70.8 \%)$ reported that their teachers value "the contribution of each member in group work" with equal mean scores $(\mathrm{M}=3.68$; $\mathrm{S} . \mathrm{D} .=0.57 \& \mathrm{M}=3.68$; $\mathrm{S} . \mathrm{D} .=$ $0.54)$. They also ranked highly the teachers' ability to "stimulate learners' communication with others" $(\mathrm{M}=$ 3.65; S.D. $=0.62$ ) and "incorporate teaching strategies that evoke interaction and thinking skills" $(\mathrm{M}=3.57$; S.D. $=0.64)$.

\section{Skill set 2: Life and Career Skills}

This set includes the skills of (a) flexibility and adaptability; (b) initiative and self-direction; (c) social and cross-cultural; (d) productivity and accountability; and (e) leadership and responsibility. The results are conveyed in tables 4 to 8 . 
Table-4: Evaluation of EFL teachers' use of 21st Century skills in terms of flexibility and adaptability

\begin{tabular}{|c|c|c|c|c|c|c|}
\hline \multirow[t]{2}{*}{ Flexibility \& Adaptability Skills } & \multicolumn{4}{|c|}{ The Scale } & \multirow[t]{2}{*}{ Mean } & \multirow[t]{2}{*}{ S.D. } \\
\hline & Excellent & Good & Fair & Poor & & \\
\hline $\begin{array}{l}\text { 1. Using up-to-date knowledge and information in the field of } \\
\text { specialization. }\end{array}$ & $\begin{array}{c}372 \\
(67.9)\end{array}$ & $\begin{array}{c}154 \\
(28.1)\end{array}$ & $\begin{array}{c}18 \\
(3.3)\end{array}$ & $\begin{array}{c}4 \\
(0.7)\end{array}$ & 3.63 & 0.59 \\
\hline $\begin{array}{l}\text { 2. Being deeply aware of current events in local, national, and global } \\
\text { contexts. }\end{array}$ & $\begin{array}{c}392 \\
(71.5)\end{array}$ & $\begin{array}{c}136 \\
(24.8)\end{array}$ & $\begin{array}{c}18 \\
(3.3)\end{array}$ & $\begin{array}{c}2 \\
(0.4)\end{array}$ & 3.68 & 0.55 \\
\hline 3. Using real-world examples in the learning process. & $\begin{array}{c}442 \\
(80.7)\end{array}$ & $\begin{array}{c}96 \\
(17.5)\end{array}$ & $\begin{array}{c}8 \\
(1.5)\end{array}$ & $\begin{array}{c}2 \\
(0.4)\end{array}$ & 3.79 & 0.47 \\
\hline $\begin{array}{l}\text { 4. Transforming content knowledge and information easily and } \\
\text { effectively. }\end{array}$ & $\begin{array}{c}422 \\
(77.0)\end{array}$ & $\begin{array}{c}112 \\
(20.4)\end{array}$ & $\begin{array}{c}10 \\
(1.8)\end{array}$ & $\begin{array}{c}4 \\
(0.7)\end{array}$ & 3.74 & 0.52 \\
\hline $\begin{array}{l}\text { 5. Creating a learning environment that encourages asking questions } \\
\text { and sharing novel ideas. }\end{array}$ & $\begin{array}{c}342 \\
(62.4)\end{array}$ & $\begin{array}{c}160 \\
(29.2)\end{array}$ & $\begin{array}{c}42 \\
(7.7)\end{array}$ & $\begin{array}{c}4 \\
(0.7)\end{array}$ & 3.53 & 0.67 \\
\hline
\end{tabular}

Overall, the students ranked the teachers' use of 21 st Century skills in terms of flexibility and adaptability as "excellent" and the majority (80.7\%) reported that the teachers' used "real-world examples in the learning process" as part of their 21st Century skills $(\mathrm{M}=3.79 ;$ S.D. $=0.47)$. Likewise, almost $77.0 \%$ valued the teachers' ability to "transform content knowledge and information easily and effectively" (M $=3.74$; S.D. $=0.52$ ) as well as the teachers' "awareness of current events in the local, national, and global contexts" (71.5\%) and "use of up-to-date knowledge and information in the field of specialisation" (67.9\%) $(\mathrm{M}=3.68$; S.D. $=0.55$ and $\mathrm{M}=3.63$; S.D. $=0.59$, respectively). Furthermore, $62.4 \%$ reported that the teachers were highly skilled in "creating a learning environment that encourages asking questions and sharing novel ideas" $(\mathrm{M}=3.53$; S.D. $=0.67)$.

Table-5: Evaluation of EFL teachers' use of 21st Century skills in terms of initiative and self-direction

\begin{tabular}{|c|c|c|c|c|c|c|}
\hline \multirow[t]{2}{*}{ Initiative \& Self-Direction Skills } & \multicolumn{4}{|c|}{ The Scale } & \multirow[t]{2}{*}{ Mean } & \multirow[t]{2}{*}{ S.D. } \\
\hline & Excellent & Good & Fair & Poor & & \\
\hline $\begin{array}{l}\text { 1. Using a variety of methods to assess learners' } \\
\text { progress and performance. }\end{array}$ & $\begin{array}{c}342 \\
(62.4)\end{array}$ & $\begin{array}{c}170 \\
(31.0)\end{array}$ & $\begin{array}{c}26 \\
(4.7)\end{array}$ & $\begin{array}{c}10 \\
(1.8)\end{array}$ & 3.54 & 0.67 \\
\hline $\begin{array}{l}\text { 2. Helping learners to build self-directed learning } \\
\text { and lifelong learning skills. }\end{array}$ & $\begin{array}{c}386 \\
(70.4)\end{array}$ & $\begin{array}{c}140 \\
(25.5)\end{array}$ & $\begin{array}{c}18 \\
(3.3)\end{array}$ & $\begin{array}{c}4 \\
(0.7)\end{array}$ & 3.66 & 0.58 \\
\hline $\begin{array}{l}\text { 3. Constantly monitoring learners' performance in } \\
\text { task-based learning. }\end{array}$ & $\begin{array}{c}422 \\
(77.0)\end{array}$ & $\begin{array}{c}114 \\
(20.8)\end{array}$ & $\begin{array}{c}10 \\
(1.8)\end{array}$ & $\begin{array}{c}2 \\
(0.4)\end{array}$ & 3.75 & 0.50 \\
\hline $\begin{array}{l}\text { 4. Respecting learners' choices of favourable } \\
\text { learning initiatives and classroom assignments. }\end{array}$ & $\begin{array}{c}376 \\
(68.6)\end{array}$ & $\begin{array}{c}152 \\
(27.7)\end{array}$ & $\begin{array}{l}14 \\
(2.6)\end{array}$ & $\begin{array}{c}6 \\
(1.1)\end{array}$ & 3.64 & 0.59 \\
\hline
\end{tabular}

Participants ranked the teachers' initiative and self-direction as "excellent" concerning all four items. The results given in Table 6 show that $77 \%$ of the EFL students who participated in the study valued positively high their teachers' skill in "constantly monitoring learners' performance in task-based learning" $(\mathrm{M}=$ 3.75; S.D. $=0.50)$. Similarly, they highly ranked the teachers' abilities to "help learners to build self-directed learning and lifelong learning skills"; "respect learners' choices of favourable learning initiatives and classroom assignments" $(\mathrm{M}=3.66$; S.D. $=0.58 \& \mathrm{M}=3.64$; S.D. $=0.59$, respectively); and, "use a variety of methods to assess learners' progress and performance" $(\mathrm{M}=3.54$; S.D. $=0.67)$.

Table-6: Evaluation of EFL teachers' use of 21st Century skills in terms of social and cross-cultural skills

\begin{tabular}{|c|c|c|c|c|c|c|}
\hline \multirow[t]{2}{*}{ Social \& Cross-Cultural Skills } & \multicolumn{4}{|c|}{ The Scale } & \multirow[t]{2}{*}{ Mean } & \multirow[t]{2}{*}{ S.D. } \\
\hline & Excellent & Good & Fair & Poor & & \\
\hline 1. Being open to criticism and others' different points of view. & $\begin{array}{c}390 \\
(71.2)\end{array}$ & $\begin{array}{c}132 \\
(24.1)\end{array}$ & $\begin{array}{c}22 \\
(4.0)\end{array}$ & $\begin{array}{c}4 \\
(0.7)\end{array}$ & 3.66 & 0.59 \\
\hline $\begin{array}{l}\text { 2. Engaging learners in extended dialogues and meaningful } \\
\text { discussion. }\end{array}$ & $\begin{array}{c}424 \\
(77.4)\end{array}$ & $\begin{array}{c}108 \\
(19.7)\end{array}$ & $\begin{array}{c}12 \\
(2.2)\end{array}$ & $\begin{array}{c}4 \\
(0.7)\end{array}$ & 3.74 & 0.53 \\
\hline 3. Participating and interacting socially with the learners. & $\begin{array}{c}422 \\
(77.0)\end{array}$ & $\begin{array}{c}102 \\
(18.6)\end{array}$ & $\begin{array}{c}22 \\
(4.0)\end{array}$ & $\begin{array}{c}2 \\
(0.4)\end{array}$ & 3.72 & 0.55 \\
\hline $\begin{array}{l}\text { 4. Showing emotional and interactive responses to learners' different } \\
\text { situations. }\end{array}$ & $\begin{array}{c}372 \\
(67.9)\end{array}$ & $\begin{array}{c}150 \\
(27.4)\end{array}$ & $\begin{array}{l}18 \\
(3.3)\end{array}$ & $\begin{array}{c}8 \\
(1.5)\end{array}$ & 3.62 & 0.62 \\
\hline 5. Appreciating effective cooperative and group work. & $\begin{array}{c}424 \\
(77.4)\end{array}$ & $\begin{array}{c}106 \\
(19.3)\end{array}$ & $\begin{array}{l}14 \\
(2.6)\end{array}$ & $\begin{array}{c}4 \\
(0.7)\end{array}$ & 3.73 & 0.54 \\
\hline $\begin{array}{l}\text { 6. Dividing the roles and learning tasks among the group members } \\
\text { fairly. }\end{array}$ & $\begin{array}{c}430 \\
(78.5)\end{array}$ & $\begin{array}{c}98 \\
(17.9)\end{array}$ & $\begin{array}{c}14 \\
(2.6)\end{array}$ & $\begin{array}{c}6 \\
(1.1)\end{array}$ & 3.74 & 0.56 \\
\hline
\end{tabular}


In terms of social and cross-cultural skills, the participants ranked highly the following teachers' skills: "dividing fairly the roles and learning tasks among the group members" (78.5\%) and "engaging learners in extended dialogues and meaningful discussion" (77.4\%) (with equal mean scores $\mathrm{M}=3.74$; S.D. $=0.56 \& \mathrm{M}=$ 3.74; S.D. $=0.53$ respectively); "appreciating effective cooperative and group work" (77.4\%) and "participating and interacting socially" (77\%) (With close mean scores $\mathrm{M}=3.73$; $\mathrm{S} . \mathrm{D} .=0.54$ and $\mathrm{M}=3.72$; S.D. $=0.55$, respectively); "being open to criticism" (M $=3.66$; S.D. $=0.59)$ and "showing emotional and interactive responses" $(\mathrm{M}=3.62$; S.D. $=0.62)$.

Table-7: Evaluation of EFL teachers' use of 21st Century skills in terms of productivity and accountability

\begin{tabular}{|c|c|c|c|c|c|c|}
\hline \multirow[t]{2}{*}{ Productivity \& Accountability Skills } & \multicolumn{4}{|c|}{ The Scale } & \multirow[t]{2}{*}{ Mean } & \multirow[t]{2}{*}{ S.D. } \\
\hline & Excellent & Good & Fair & Poor & & \\
\hline $\begin{array}{l}\text { 1. Providing constructive feedback on learners' work and in-class } \\
\text { performance. }\end{array}$ & $\begin{array}{c}364 \\
(66.4)\end{array}$ & $\begin{array}{c}168 \\
(30.7)\end{array}$ & $\begin{array}{c}12 \\
(2.2)\end{array}$ & $\begin{array}{c}4 \\
(0.7)\end{array}$ & 3.63 & 0.57 \\
\hline 2. Respecting the ethics of the teaching profession. & $\begin{array}{c}468 \\
(85.4)\end{array}$ & $\begin{array}{c}72 \\
(13.1)\end{array}$ & $\begin{array}{c}6 \\
(1.1)\end{array}$ & $\begin{array}{c}2 \\
(0.4)\end{array}$ & 3.84 & 0.43 \\
\hline $\begin{array}{l}\text { 3. Demonstrating ethical behaviour, commitment, and taking } \\
\text { responsibility. }\end{array}$ & $\begin{array}{c}386 \\
(70.4)\end{array}$ & $\begin{array}{c}146 \\
(26.6)\end{array}$ & $\begin{array}{c}14 \\
(2.6)\end{array}$ & $\begin{array}{c}2 \\
(0.4)\end{array}$ & 3.67 & 0.54 \\
\hline
\end{tabular}

As can be seen in Table 7, the participants rated highly the teachers' 21 st Century skills in terms of productivity and accountability regarding all three items. "Respecting the ethics of the teaching profession" was ranked highly by $85.4 \%$ and had the highest mean score $(\mathrm{M}=3.84$; S.D. $=0.43)$. Although the mean scores of Items 1 and 3 were lower than the mean score for Item 2, the percentage of students who ranked them highly was still significant $(70.4 \%$ and $66.4 \%$ respectively). Based on the mean scores $(\mathrm{M}=$ 3.67; S.D. $=0.54)$ and $(\mathrm{M}=3.63$; S.D. $=0.57)$, it is evident that the participants respect their teachers' efforts to "demonstrate ethical behaviour, commitment, and taking responsibility" and "providing constructive feedback on learners' work and in-class performance."

Table-8: Evaluation of EFL teachers' use of 21st Century skills in terms of leadership and responsibility

\begin{tabular}{|c|c|c|c|c|c|c|}
\hline \multirow[t]{2}{*}{ Leadership \& Responsibility Skills } & \multicolumn{4}{|c|}{ The Scale } & \multirow[t]{2}{*}{ Mean } & \multirow[t]{2}{*}{ S.D. } \\
\hline & Excellent & Good & Fair & Poor & & \\
\hline $\begin{array}{l}\text { 1. Introducing tasks that develop learners' interpersonal and self- } \\
\text { development skills. }\end{array}$ & $\begin{array}{c}344 \\
(62.8)\end{array}$ & $\begin{array}{c}184 \\
(33.6)\end{array}$ & $\begin{array}{c}16 \\
(2.9)\end{array}$ & $\begin{array}{c}4 \\
(0.7)\end{array}$ & 3.58 & 0.59 \\
\hline 2. Managing the classroom effectively and smoothly. & $\begin{array}{c}400 \\
(73.0)\end{array}$ & $\begin{array}{c}128 \\
(23.4)\end{array}$ & $\begin{array}{c}14 \\
(2.6)\end{array}$ & $\begin{array}{c}6 \\
(1.1)\end{array}$ & 3.68 & 0.58 \\
\hline $\begin{array}{l}\text { 3. Demonstrating flexibility and responsiveness to different } \\
\text { classroom situations. }\end{array}$ & $\begin{array}{c}362 \\
(66.1)\end{array}$ & $\begin{array}{c}156 \\
(28.5)\end{array}$ & $\begin{array}{c}26 \\
(4.7)\end{array}$ & $\begin{array}{c}4 \\
(0.7)\end{array}$ & 3.60 & 0.62 \\
\hline
\end{tabular}

The results, as shown in Table 8 , indicate that more than two-thirds of the participants $(73 \%)$ rated highly the teachers' 21 st Century skill of "managing the classroom effectively and smoothly" in terms of leadership and responsibility skills $(\mathrm{M}=3.68$; S.D. $=$ $0.58) .66 .1 \%$ and $62.8 \%$ of the participants rated Items 1 and 3 closely. The Saudi EFL female students significantly valued their teachers' skill in "demonstrating flexibility and responsiveness to different classroom situations" and "introducing tasks that develop learners' interpersonal and selfdevelopment skills" $(\mathrm{M}=3.60$; S.D. $=0.62)$ and $(\mathrm{M}=$ 3.58; S.D. = 0.59).

\section{Skill set 3: IMTS Skills}

These skills include (a) information literacy; (b) media literacy; and (c) ICT literacy.

Table-9: Evaluation of EFL teachers' use of 21st Century skills in terms of information literacy

\begin{tabular}{|c|c|c|c|c|c|c|}
\hline \multirow[t]{2}{*}{ Information Literacy Skills } & \multicolumn{4}{|c|}{ The Scale } & \multirow[t]{2}{*}{ Mean } & \multirow[t]{2}{*}{ S.D. } \\
\hline & Excellent & Good & Fair & Poor & & \\
\hline $\begin{array}{l}\text { 1. Developing learners' skills to search for reliable sources of } \\
\text { information. }\end{array}$ & $\begin{array}{c}360 \\
(65.7)\end{array}$ & $\begin{array}{c}164 \\
(29.9)\end{array}$ & $\begin{array}{c}22 \\
(4.0)\end{array}$ & $\begin{array}{c}2 \\
(0.4)\end{array}$ & 3.61 & 0.58 \\
\hline $\begin{array}{l}\text { 2. Integrating information and communication technology (ICT) } \\
\text { effectively into the learning process. }\end{array}$ & $\begin{array}{c}400 \\
(73.0)\end{array}$ & $\begin{array}{c}132 \\
(24.1)\end{array}$ & $\begin{array}{c}12 \\
(2.2)\end{array}$ & $\begin{array}{c}4 \\
(0.7)\end{array}$ & 3.69 & 0.55 \\
\hline
\end{tabular}

Table 9 reveals that the mean score of Item 2 "integrating information and communication technology (ICT) effectively" reflected a high level of response (M
$=3.69 ;$ S.D. $=0.55)$. Also, more than half of the respondents $(65.7 \%)$ ranked highly their teachers' skill 
Table-10: Evaluation of EFL teachers' use of 21st Century skills in terms of media literacy

\begin{tabular}{|c|c|c|c|c|c|c|}
\hline \multirow[t]{2}{*}{ Media Literacy Skills } & \multicolumn{4}{|c|}{ The Scale } & \multirow{2}{*}{ Mean } & \multirow[t]{2}{*}{ S.D. } \\
\hline & Excellent & Good & Fair & Poor & & \\
\hline $\begin{array}{l}\text { 1.Demonstrating awareness of the most recent digital learning } \\
\text { resources. }\end{array}$ & $\begin{array}{c}400 \\
(73.0)\end{array}$ & $\begin{array}{c}132 \\
(24.1)\end{array}$ & $\begin{array}{c}16 \\
(2.9)\end{array}$ & - & 3.70 & 0.52 \\
\hline $\begin{array}{l}\text { 2. Directing learners to understand the effectiveness of digital } \\
\text { learning. }\end{array}$ & $\begin{array}{c}368 \\
(67.2)\end{array}$ & $\begin{array}{c}142 \\
(25.9)\end{array}$ & $\begin{array}{c}30 \\
(5.5)\end{array}$ & $\begin{array}{c}8 \\
(1.5)\end{array}$ & 3.59 & 0.66 \\
\hline
\end{tabular}

The results shown in Table 10 indicate that a substantial number of Saudi EFL female students (73\%) highly rated teachers' use of 21 st Century skills in terms of media literacy, specifically their "awareness of the most recent digital learning resources" $(\mathrm{M}=3.70$; S.D. $=$
0.52). Likewise, more than half $(67.2 \%)$ valued the teachers' ability to "direct learners to understand the effectiveness of digital learning" $(\mathrm{M}=3.59$; S.D. $=$ $0.66)$.

Table-11: Evaluation of EFL teachers' use of 21st Century skills in terms of ICT literacy

\begin{tabular}{|c|c|c|c|c|c|c|}
\hline \multicolumn{2}{|c|}{ ICT literacy Skills } & \multicolumn{3}{|c|}{ The Scale } & \multirow{2}{*}{ Mean } & \multirow{2}{*}{ S.D. } \\
\cline { 2 - 5 } & $\begin{array}{c}\text { Excel } \\
\text { lent }\end{array}$ & Good & Fair & Poor & & \\
\hline $\begin{array}{c}\text { 1. Encouraging learners to implement available } \\
\text { digital technologies to support their learning. }\end{array}$ & $\begin{array}{c}394 \\
(71.9)\end{array}$ & $\begin{array}{c}118 \\
(21.5)\end{array}$ & $\begin{array}{c}26 \\
(4.7)\end{array}$ & $\begin{array}{c}10 \\
(1.8)\end{array}$ & 3.64 & 0.66 \\
\hline $\begin{array}{l}\text { 2. Helping learners to master using digital } \\
\text { technologies in their learning. }\end{array}$ & $\begin{array}{c}392 \\
(71.5)\end{array}$ & $\begin{array}{c}128 \\
(23.4)\end{array}$ & $\begin{array}{c}22 \\
(4.0)\end{array}$ & $\begin{array}{c}6 \\
(1.1)\end{array}$ & 3.65 & 0.61 \\
\hline
\end{tabular}

As seen in Table 11, the two items relating to ICT literacy were both rated highly by the respondents. An almost equal number of participants (71.9\%) and $(71.5 \%)$ reported that the EFL teachers are able to "help them to master using digital technologies in their learning" and "encourage them to implement available digital technologies to support their learning" $(\mathrm{M}=3.65$; S.D. $=0.61 \& \mathrm{M}=3.64 ;$ S.D. $=0.66$ respectively).

Table-12: Overall evaluation of EFL teachers' use of 21st Century skills

\begin{tabular}{|l|c|c|}
\hline \multicolumn{1}{|c|}{ 21st Century skills } & Mean & S.D. \\
\hline Learning and Innovation Skills & $\mathbf{3 . 6 5}$ & $\mathbf{0 . 0 1}$ \\
\hline$\bullet$ Creativity and Innovation & 3.64 & 0.04 \\
\hline$\bullet$ Critical Thinking and Problem Solving & 3.66 & 0.05 \\
\hline$\bullet$ Communication and Collaboration & 3.64 & 0.04 \\
\hline Life and Career Skills & $\mathbf{3 . 6 7}$ & $\mathbf{0 . 0 4}$ \\
\hline$\bullet$ Flexibility and Adaptability & 3.67 & 0.11 \\
\hline$\bullet$ Initiative and Self-Direction & 3.65 & 0.10 \\
\hline$\bullet$ Social and Cross-Cultural Skills & 3.70 & 0.04 \\
\hline$\bullet$ Productivity and Accountability & 3.71 & 0.12 \\
\hline$\bullet$ Leadership and Responsibility & 3.62 & 0.06 \\
\hline Information, Media and Technology Skills & $\mathbf{3 . 6 5}$ & $\mathbf{0 . 0 0}$ \\
\hline$\bullet$ Information Literacy & 3.65 & 0.04 \\
\hline$\bullet$ Media Literacy & 3.64 & 0.06 \\
\hline$\bullet$ ICT & 3.64 & 0.01 \\
\hline
\end{tabular}

As shown in Table 12, the results indicate that the respondents value the EFL teachers' use of critical thinking and problem-solving skills $(\mathrm{M}=3.66$; $\mathrm{SD}=$ $0.05)$, as a sub-dimension in the learning and innovation skill set, quite highly. The two sub-dimensions: communication and collaboration skills and creativity and innovation skills gained equal mean scores $(\mathrm{M}=$ 3.64; SD = 0.04).

Based on the results in Table 12, Saudi EFL female students rate EFL teachers' use of life and career skills extremely highly. On the basis of the mean scores, the items ranked highest relate to productivity and accountability skills $(M=3.71$; S.D. $=0.12)$, then, social and cross-cultural skills $(\mathrm{M}=3.70 ;$ S.D. $=0.04)$, and followed by flexibility and adaptability skills $(\mathrm{M}=3.67$; S.D. $=0.11)$. These are followed by initiative and selfdirection skills and leadership and responsibility skills $(\mathrm{M}=3.65 ;$ S.D. $=0.10 ; \mathrm{M}=3.62 ;$ S.D. $=0.06$ respectively). 
Moreover, the figures given in Table 12 indicate that EFL students value all three sub-dimensions of IMTS skills. The mean scores were almost similar for information literacy skills $(\mathrm{M}=3.65 ; \mathrm{SD}=0.04)$, media literacy skills $(\mathrm{M}=3.64 ; \mathrm{SD}=0.06)$, and ICT literacy skills $(\mathrm{M}=3.64 ; \mathrm{SD}=0.01)$. Generally, the results indicate that the respondents value the EFL teachers' use of life and career skills $(\mathrm{M}=3.67$; $\mathrm{SD}=0.04)$ quite higher than learning and innovation skills and information, media and technology skills $(\mathrm{M}=3.65$; S.D. $=0.01 ; \mathrm{M}=3.65 ;$ S.D. $=0.00$ respectively).

\section{Research Question 2}

Based on the results in Figure 1, EFL female students' views concerning the impact of the teachers' use of 21 st Century skills on their language skills are positive.

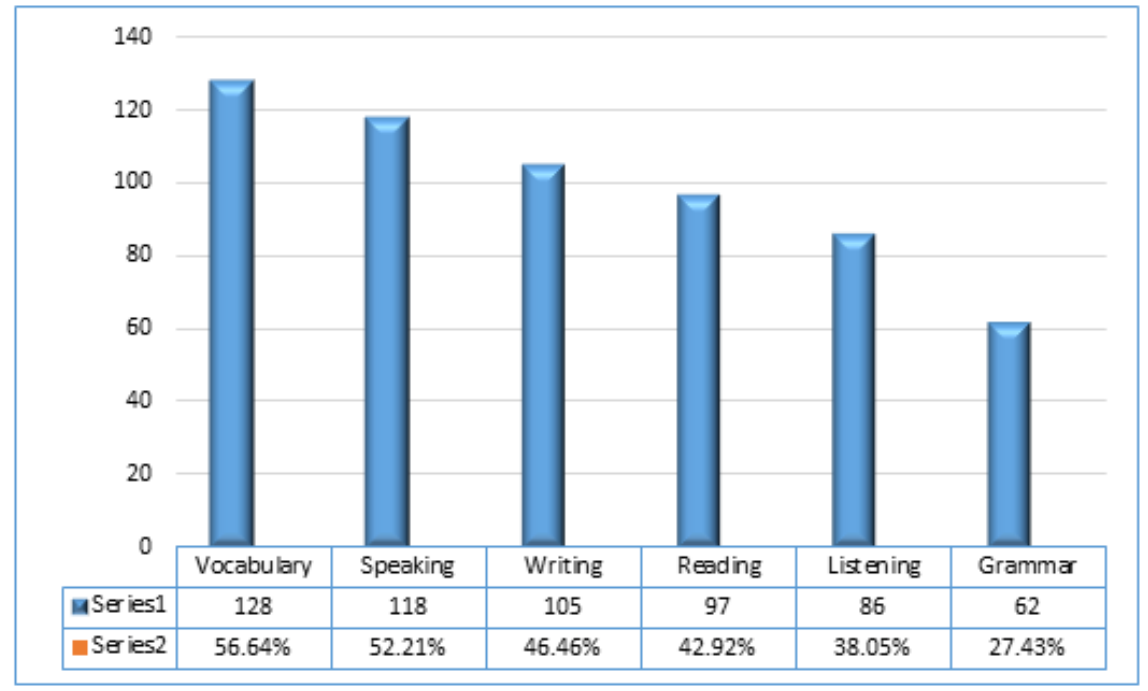

Fig-1: EFL students' views concerning the impact of teachers' use of 21st Century skills on their language skills

On the basis of the data given in Figure 1, it appears that EFL female students $(128 / 56.64 \%)$ found that the language aspect that was clearly improved due to EFL teachers' integration of 21 st Century skills in the teaching-learning process was vocabulary followed by speaking skills $(118 / 52.21 \%)$. Moreover, the participants also rated highly the impact of EFL teachers' 21st Century skills on writing (105 / 46.46\%) and reading (97/42.92\%) skills. The lowest impact of the integration of the $21^{\text {st }}$ Century skills in the teachinglearning process according to the respondents was on listening skills $(86 / 38.05 \%)$ and knowledge of grammar (62 / 27.43\%).

\section{DISCUSSION OF THE FINDINGS}

This study was conducted to explore the value that Saudi EFL female students give to their teachers' use of 21 st Century skills and the impact of the integration of such skills in the classroom on language learning. The research findings indicate that the participants ranked their teachers' 21 st Century skills as "excellent" concerning all the items in the "learning and innovation" skill set. The sub-dimension "critical thinking and problem-solving skills" received the highest mean score. A possible explanation for this might lie in the features of the EFL textbook " $Q$ : Skills for Success"; specifically the fact that it (a) allows the EFL teachers to use a question-centered approach that encourages students to think critically, (b) provides videos in every unit to evoke critical thinking, and (c) delivers online activities that enhance critical thinking and problem-solving skills. This result is in accord with Norahmi's [22] statement that the 21st Century teacher should design regular dynamic learning activities to facilitate more critical-thinking learning opportunities. It is also in agreement with Oudeweetering and Voogt's [20] findings which showed that classroom activities fostered 21 st Century skills, specifically, innovative thinking and critical thinking skills. Moreover, the result aligns with the innovative activities that Asri [27] recommends be implemented in 21st Century EFL classrooms to enhance critical thinking during language learning.

Furthermore, it was found that the participants also rated all their teachers' performance in terms of all items in the "life and career" skill set as "excellent". The sub-dimension "social and cross-cultural skills" obtained the highest mean score. There are several possible explanations for this result. A possible explanation may be the use of iTools Online during classroom presentations that allows for a higher level of interaction and engagement in dialogues and discussion especially when videos and audio recordings are used in the classroom. Another possible explanation is the PYP EFL teachers' ability to be fair, open to criticism, be sensitive to certain situations, and to socially interact with the learners. The high ranking of the "life and career" skill set in this study is in line with the results obtained by Ahonen and Kinnunen [15] and Ongardwanich et al. [16] in their respective studies. 
The participants also ranked their teachers' "IMTS Skills as "excellent" and this in relation to all items grouped under this category. Moreover, the results showed almost identical mean scores relating to the three sub-dimensions. This result may due to the strong belief of EFL students in technology as a success factor to 21 st Century learning. EFL teachers are expected to integrate technology in their classes as most of the language tasks are worked out using the iTools Online and/or through the interactive features of the eBook versions of the Student Book. In general, it can be concluded that the use of digital tools is a key factor in the success of EFL students in the PYP. This result is consistent with the results obtained by Thang et al. [24], Norahmi [22], Ahmadi [30], and Bedir [7] that recommend using technology to enhance the levels of interaction between EFL teachers and learners, develop thinking skills, and facilitate a student-centered approach. Moreover, this result is in agreement with Asri [27] who suggests that EFL teachers should allow students to use technology effectively in different situations, such as using it as a tool to research, organise, and communicate information or to manage the flow of information from a wide range of sources.

As indicated by the results of the one-question questionnaire, the responses of Saudi EFL female students emphasised the impact that EFL teachers' use of 21st Century skills has on their language skills. This study found that the EFL students were satisfied with their improvement in their language skills which, in turn, was reflected in their positive assessment of their teachers' ability to employ 21 st Century skills in their teaching. The results indicate that the highest impact is on the students' vocabulary and speaking skills. One possible explanation behind the improvement in vocabulary might be that both EFL teachers and students believe in the critical role of vocabulary acquisition in language learning. Thus, in the PYP, vocabulary is taught using the four language areas in meaningful activities. For example, in listening and reading classes, vocabulary is essential for in-depth comprehension. Thus, EFL teachers ensure that students are familiar with the meaning, pronunciation, and spelling of new vocabulary before giving out any learning tasks. Hence, EFL teachers expose students to new vocabulary and provide a variety of activities to practice the new vocabulary using decoding, fluency, and comprehension skills. Moreover, EFL teachers give a great deal of importance to speaking activities and create situations where students have the opportunity to use words in a sentence using the correct pronunciation, grammar, and context. They, further, provide the opportunity to practice vocabulary before moving on to more complicated speaking tasks. Likewise, in writing tasks, students are taught how to select the appropriate vocabulary based on grammar, meaning, and context suitability before they start to jot down their ideas. This result is consistent with the findings obtained by Ahmadi [30], Kan and Murat [8] and Thang et al. [24] who reported on the necessity of implementing different teaching methods that increase individuals' language learning.

With regard to the results relating to speaking skills, there are several possible explanations. A possible explanation may be due to the EFL teachers' use of different speaking tasks and subject projects such as debates, dramatic reenactments, interviews, newscasts, question-and-answer activities and storytelling that provide students with numerous chances to practice using the language for oral communication. This result is in agreement with the results obtained by Handayani [23] that emphasised the vital role played by EFL teachers and the need to switch from traditional classes to more innovative classes that promote activities that enhance 21 st Century skills.

Another possible explanation supporting the speaking skills result is the use of iTools Online which is an all-in-one communication resource in the classroom that the teacher can use to enhance oral communication and interaction. This tool provides interactive audio and video materials. It also hosts a forum through which students can discuss unit questions and reflect on their learning. In short, the EFL students find that these online features that they are exposed to daily help them enhance their oral performance.

This result further supports the conclusion drawn by Bedir [7], Handayani [23], Thang et al. [24] and Yüksel [25] that using technology in the EFL classroom increases students' abilities to acquire language skills. Moreover, Ahmadi [30] and Norahmi [22] report that the use of technology-based activities promotes self-confidence and motivation to learn a foreign language effectively. Likewise, this result seems to be consistent with that obtained by Howlett and Waemusa [31,39] who found that students were ready and willing to learn EFL using mobile devices.

Generally, EFL students seem well-satisfied with their language progress in all the language skills and positively rate the impact of their teachers' use of 21st Century skills on their teaching of the English language in the PYP.

\section{CONCLUSION AND RECOMMENDATIONS}

This paper explored the Saudi EFL female students' perception of their teachers' use of $21 \mathrm{st}$ Century skills and its impact on improving language skills and aspects. The first quantitative data phase for this study was gathered from 548 PYP EFL female students (28.51\% of the population) and the second data phase explored the views of 226 PYP EFL students $(41.24 \%)$ on the impact of EFL teachers' use of $21 \mathrm{st}$ Century skills on their language skills acquisition. The results revealed that the Saudi EFL female students have a positive view of their teachers' use of $21 \mathrm{st}$ 
Century skills, as reflected in their responses to all items in the questionnaire that they rated "excellent". Moreover, the results indicated that "life and career" skill set and its sub-dimension "social and cross-cultural skills" obtained the highest mean scores. The results emphasised the positive impact of EFL teachers' use of 21 st Century skills on the students' language skills, particularly their acquisition of vocabulary and their speaking skills.

The following academic recommendations can, therefore, be proposed based on the relatively positive results obtained through the two questionnaires.

Firstly, although the teachers' use of $21 \mathrm{st}$ Century skills was positively evaluated by their students, this research highlights the importance of teachers' professional development programmes to ensure that they are able to integrate 21 st Century skills in the teaching-learning process. Teachers need to be trained to integrate 21 st Century skills into their teaching and model these skills for their students. Teachers must remain up-to-date in the rapidly changing field of instruction.

Secondly, given the positive response of EFL students to the integration and use of 21 st Century skills, curricula in schools and/or in universities should be reconstructed to equip students with the necessary 21 st Century skills for their future success. Additionally, language teachers should be keen and ready to blend the $4 \mathrm{Cs}$ more thoughtfully into learnercentered content that promotes students' interactivity and innovation.

Thirdly, based on the EFL students' satisfaction with their language progress due to teachers' use of 21 st Century skills, these findings recommend that teachers employ a variety of activities, techniques, and methods to teach EFL. More specifically, they should be aware of using techniques that promote students' $4 \mathrm{Cs}$ in order to augment students' future success and prepare them well as independent and curious individuals.

Given these promising results, this study has the potential to lay the foundation for future work on 21 st Century skills, in order to promote its implementation in EFL classrooms. Further work is required to examine the extent to which EFL teachers and students are meeting current expectations for $21 \mathrm{st}$ Century learning. There is abundant room for further progress in exploring EFL teachers' reflections upon the probability and relevance of developed curricular guidelines for 21st Century competencies. However, more research on this topic needs to be undertaken to obtain insights into how EFL teachers project themselves as teachers of the 21 st Century and how they evaluate their teaching competences.

\section{Limitations of the study}

This study has resulted in a number of significant findings. However, the participants consisted exclusively of female students and therefore the potential impact of gender on the finding was beyond the scope of this study. Moreover, this study has only provided data on perspectives held by students; a broader study that includes the perceptions of both students and teachers could be conducted to add to the body of research in this area.

\section{ACKNOWLEDGEMENTS}

The researcher wishes to thank the EFL Saudi female students involved in this study for their high level of responsiveness. Thanks are also extended to the Deanship for Academic Services and the ELC at Taibah University for their invaluable administrative support.

\section{REFERENCES}

1. Saavedra, A. R., \& Opfer, V. D. (2012a). Learning 21 st-century skills requires 21 st-century teaching. The Phi Delta Kappan, 94(1), 8-13. Retrieved from http://www.jstor.org/stable/41763587

2. OECD. (2005a). definition and selection of key competencies. Retrieved from http://www.oecd.org/pisa/35070367.pdf

3. Orr, D., Rimini, M., \& Van-Damme, D. (2015). Open educational resources: A catalyst for innovation. Paris: Center for Educational Research and Innovation, OECD Publishing, https://doi.org/http://dx.doi.org/10.1787/978926424 7543-en

4. Saavedra, A. R., \& Opfer, V. D. (2012b). Teaching and learning 21st century skills: Lessons from the learning sciences. RAND Corporation. Asia Society. Retrieved from https://www.aare.edu.au/data/publications/2012/Sa avedra12.pdf.

5. Trilling, B., \& Fadel, C. (2009). 21st century skills: Learning for life in our times. San Francisco, CA, USA: Jossey-Bass.

6. Dede, C. (2009). Comparing frameworks for $21 \mathrm{st}$ century skills. In J. B. \& R. Brandt (Ed.), 21st century skills: Rethinking how students learn (pp. 51-76). Bloomington, IN: Solution Tree Press.

7. Bedir, H. (2019). Pre-service ELT teachers' beliefs and perceptions on 21 st century learning and innovation skills (4Cs). Journal of Language and Linguistic Studies, 15(1), 231-246. https://doi.org/10.17263/jlls.547718

8. Kan, A., \& Murat, A. (2018). Investigation of prospective science teachers' 21st century skill competence perceptions and attitudes toward STEM. International Online Journal of Educational Sciences, 10(4), 251-272. Retrieved from https://www.iojes.net

9. Prasertcharoensuk, T., Somprach, K., \& Ngang, T. K. (2015). Influence of teacher competency factors and students' life skills on learning achievement. Procedia - Social and Behavioral Sciences, 186, 
$566-572$.

https://doi.org/10.1016/j.sbspro.2015.04.021

10. Sahin, M. C. (2009). Instructional design principles for 21 st century learning skills. Procedia Social and Behavioral Sciences, 1(1), 1464-1468.

11. Christensen, U., \& Howe, N. (2019). Preparing the workforce of tomorrow: Learning and development for a changing world. Area9 Lyceum. Retrieved from Learning-and-Development-for-a-ChangingWorld-2.13.19.pdf

12. Mahat, M., Bradbeer, C., Byers, T., \& Imms, W. (2018). Innovative learning environments and teacher change: Defining key concepts. Melbourne: University of Melbourne, LEaRN. Retrieved from http://www.iletc.com.au/publications/reports\%0AI SBN:

13. OECD. (2005b). Teachers matter: Attracting, developing and retaining effective teachers. OECD Publishing,

Paris. https://doi.org/10.1787/9789264022157-ja

14. Pheeraphan, N. (2013). Enhancement of the 21st century skills for Thai higher education by integration of ICT in classroom. Procedia - Social and Behavioral Sciences, 103, 365-373. https://doi.org/10.1016/j.sbspro.2013.10.346

15. Ahonen, A. K., \& Kinnunen, P. (2015). How do students value the importance of twenty-first century skills? Scandinavian Journal of Educational Research, 59(4), 395-412. https://doi.org/10.1080/00313831.2014.904423

16. Ongardwanich, N., Kanjanawasee, S., \& Tuipae, C. (2015). Development of 21st century skill scales as perceived by students. Procedia - Social and Behavioral Sciences, 191, 737-741. https://doi.org/10.1016/j.sbspro.2015.04.716

17. Jan, H. (2017). Teacher of 21st century: Characteristics and development. Research on Humanities and Social Sciences, 7(9), 50-54. Retrieved from www.iiste.org

18. Kobalia, K., \& Garakanidze, E. (2010). The professional competencies of the 21st century teacher. Problems of Education in the 21st Century, 20, 104-108.

19. Kostanjevec, S., Kozina, F., \& Erjavšek, M. (2018). The relationship between teachers' education and their self-perceived competence for teaching home economics. Problems of Education in the 21st Century, 76(2), 175-188.

20. Oudeweetering, K., \& Voogt, J. (2018). Teachers' conceptualization and enactment of twenty-first century competences: Exploring dimensions for new curricula. The Curriculum Journal, 29(1), 116133. https://doi.org/10.1080/09585176.2017.1369136

21. Tican, C., \& Deniz, S. (2018). Pre-service teachers' opinions about the use of 21 st century learner and 21st century teacher skills. European Journal of Educational Research, 8(1), 181-197. https://doi.org/10.12973/eu-jer.8.1.181
22. Norahmi, M. (2017). 21st-century teachers: The students' perspectives. Journal on English as a Foreign Language, 7(1), 77-96. https://doi.org/10.23971/jefl.v7i1.538

23. Handayani, N. (2017). Becoming the effective English teachers in the 21st century: What should know and ehat should do? In 1st English Language and Literature International Conference (ELLiC), 6May, 2017 (pp. 156-164). University of Muhammadiyah Semarang.

24. Thang, S., Sim, L., Mahmud, N., Lin, L., Zabidi, N., \& Ismail, K. (2014). Enhancing 21st century learning skills via digital storytelling: Voices of Malaysian teachers and undergraduates. Procedia Social and Behavioral Sciences, 118, 489-494.

25. Yüksel, H. G. (2014). Teachers of the future: Perceived teaching competences and visions of preservice English language teachers. International Journal of Human Sciences., 11(2), 27-39.

26. Care, E., Kim, H., Vista, A., \& Anderson, K. (2018). Education system alignment for 21st century skills: Focus on assessment. Center for Universal Education at The Brookings Institution., 41. Retrieved from https://cutt.us/0EekQ

27. Asri, A. (2019). Designing a 21st century assessment in EFL learning context. In International Seminar on Language, Education, and Culture, KnE Social Sciences (pp. 335-348). https://doi.org/10.18502/kss.v3i10.3915

28. Ball, A., Joyce, H. D., \& Anderson-Butcher, D. (2016). Exploring 21st century skills and learning environments for middle school youth. International Journal of School Social Work, 1(1), 1-15. https://doi.org/10.4148/2161-4148.1012

29. The Glossary of Education Reform. (2014). 21st century skills. Retrieved from https://www.edglossary.org/21st-century-skills/

30. Ahmadi, M. R. (2018). The use of technology in English language learning: A literature review. International Journal of Research in English Education, 3(2), 115-125.

31. Howlett, G., \& Waemusa, Z. (2018). 21st century learning skills and autonomy: Students' perceptions of mobile devices in the Thai EFL context. Teaching English with Technology, 19(1), 72-85.

32. Saudi Vision 2030. (2016). Saudi Arabia's Vision for 2030. Retrieved from https://vision2030.gov.sa/download/file/fid/417.

33. Learning Metrics Task Force (LMTF). (2013). Toward universal learning: Recommendations from the learning metrics task force. Montreal and Washington, D. C.: UNESCO Institute for Statistics and Center for Universal Education at the Brookings Institution. Retrieved from https://cutt.us/ErK4Q

34. Bialik, M., \& Fadel, C. (2015). Skills for the 21st century: What should students learn? Boston, Massachusetts: Center for Curriculum Redesign.

35. The Partnership for 21st Century Skills (P21). (2009). Framework for 21st century learning. 
Retrieved from http://teacherrambo.com/file.php/1/21st_century_s kills.pdf.

36. Ontario Ministry of Education. (2016). Towards defining 21st century competencies for Ontario:21st century competencies. Ontario: The Ontario Public Service. Retrieved from 21cl21stcenturycompetencies.pdf

37. The Partnership for 21st Century Skills (P21). (2019). Framrwork for 21st century learning definition. Retrieved from https://cutt.us/MBSck
38. The European Parliament and the Council of the European Union (EPCEU). (2006) Recommendation of the European parliament and of the council of 18 December 2006 on key competences for lifelong learning. Retrieved from https://cutt.us/OxByo

39. Chalkiadaki, A. (2018). A systematic literature review of 21 st century skills and competencies in primary education. Ernational Journal of Instruction, 11(3), $1-16$. 